\title{
GRAFT COMPATIBILITY BETWEEN EUROPEAN PEAR CULTIVARS AND EAST MALLING "C" ROOTSTOCK ${ }^{\prime}$
}

\author{
BRUNO DALAZEN MACHADO ${ }^{2}$, MAICON MAGRO $^{3}$, LEO RUFATO $^{4}$, \\ AMAURI BOGO $^{4}$, AIKE ANNELIESE KREZTSCHMAR ${ }^{4}$
}

\begin{abstract}
Graft incompatibility is one of the main factors limiting european pear production in Brazil. At present, there is no clear indication of the best combination(s) of european pear cultivars and quince rootstocks for graft compatibility. The study evaluated the graft compatibility for combinations of european Abbè Fetel, Rocha and Williams pear cultivars grafted onto the EMC quince rootstock. The experiment was performed in a commercial european pear orchard in the Urupema municipality, in State of Santa Catarina, during the 2011/12,2012/13 and 2013/14 growing seasons. The plant growth variables comprised the section increment $(\mathrm{mm})$ in the trunk diameter in the graft union region of cultivars and rootstocks; difference in the diameter of the graft for cultivars and rootstocks; "translocated" incompatibility; "located" incompatibility and the vascular connection in the graft union region, which was assessed by immersing the bases of the plants in a $0.08 \%$ succinic acid solution. There were "located" and "translocated" incompatibility between the european Williams pear cultivar and the EMC rootstock based on the vascular discontinuity in the graft union region, which prevented the translocation of succinic acid stain. Thus, the Williams/EMC combination is considered incompatible and it is not recommended for use in commercial orchards. The Rocha/EMC and Abbè Fetel/EMC are considered partially incompatible combinations and showed good development eight years after planting.
\end{abstract}

Index Terms: compatibility level; located incompatibility; translocated incompatibility; Pyrus communis L.; vascular union; vigor.

\section{COMPATIBILIDADE DE ENXERTIA ENTRE CULTIVARES DE PEREIRAS EUROPEIAS E PORTAENXERTOS DE MARMELEIRO EAST MALLING "C"}

RESUMO - A incompatibilidade de enxertia é um dos principais fatores limitantes da produção de peras no Brasil. Até o presente, não há uma indicação da melhor combinação de cultivares de pereiras-europeias e porta-enxertos de marmeleiros com compatibilidade de enxertia. $\mathrm{O}$ estudo avaliou a compatibilidade de enxertia entre as combinações de pereiras europeias Abbè Fetel, Rocha e Williams enxertadas sobre o porta-enxerto de marmeleiro EMC. O experimento foi conduzido em pomar comercial de pereira-europeia no município de Urupema, estado de Santa Catarina, durante as estações de crescimento de 2011/2012, 2012/2013 e 2013/2014. As variáveis de crescimento de plantas foram: o incremento do diâmetro do tronco na região de união do enxerto entre as cultivares e o porta-enxerto $(\mathrm{mm})$; diferença de diâmetro do enxerto das cultivares e do porta-enxerto, incompatibilidade "translocada", incompatibilidade "localizada" e a conexão vascular na região da enxertia, o qual foi determinada por meio de imersão da base da planta em solução com ácido succínico a $0,08 \%$. Houve incompatibilidade localizada e translocada entre a cultivar de pereira-europeia Williams e o porta-enxerto EMC, baseado na descontinuidade vascular na região de união do enxerto, o qual impediu a translocação do ácido succínico. A combinação Williams/EMC é considerada incompatível e não é recomendada para uso em pomares comerciais. As combinações Rocha/EMC e Abbè Fetel/EMC são consideradas combinações parcialmente compatíveis e apresentaram bom desenvolvimento após 8 anos do plantio.

Termos para indexação: nível de compatibilidade; incompatibilidade "localizada"; incompatibilidade "translocada"; Pyrus communis L.; união vascular; vigor.

\footnotetext{
1(Paper 008-16). Received January 12, 2016. Accepted July 06, 2016.

${ }^{2}$ Professor, Federal Institute of Santa Catarina, IFSC/Urupema/SC, Highway Senadinho, S/N, CEP: 88625-000, Urupema-SC, Brasil. E-mail: bruno.dalazem@ifsc.edu.br

${ }^{3}$ Crop Production Graduate student, Santa Catarina State University, CAV/UDESC. Lages - SC. E-mail: maico.magro@hotmail.com ${ }^{4}$ Professor, Santa Catarina State University, CAV/UDESC. Lages - SC. E-mail: leo.rufato@udesc.br; amauri.bogo@udesc.br; aike. kreztschmar@udesc.br
} 


\section{INTRODUCTION}

In Brazil, the highlands of Santa Catarina State present favorable areas for european pear production with high cold demand (Pyrus communis L.) (IUCHI et al., 2008). Currently, brazilian pear production is not sufficient to satisfy the domestic marketand there is a significant demand for imports. Brazil is the second largestpear importer in the world (FACHINELLO, 2011).

Commercial pear varieties worldwide are grafted on to Pyrus and quince (Cydonia oblonga Mill.) rootstocks. Quince rootstocks have been used widely because of two beneficial characteristics of the grafted trees, size reduction and precocity. However, most pear cultivars exhibit graft incompatibility when grafted onto quince rootstocks because of physiological and biochemical factors (FRANCESCATTO et al., 2010). In Brazil, there is the current trend of using quince rootstock in european pear orchards with the aim of producing less vigorous plants with early fruit set, thereby allowing a high planting density (MACHADO et al., 2013). Grafting is frequently used to improve the plant propagation features, where rootstock grafting is connected to the vigor and selected features of the cultivars in terms of the trunk, stem, leaves, flowers, or fruit (JANICK, 2009).

Graft compatibility is defined as a sufficiently close genetic (taxonomic) relation ship between the cultivar and rootstock to allow the formation of a successful graft union, assuming that all other factors (such as technique, temperature) are satisfactory. Graft unions may lead to incompatibility problems among the grafted parts of plants, there by resulting in more plant death. Many common pear cultivars exhibit graft incompatibility when grafted onto quince (ERMEL et al., 1999). The graft interface exhibits a vascular discontinuity that is associated with the presence of necrotic cells in the wood and bark, the inclusion of unlignified cells in the wood, and invaginations or breaks in the cambium. Pina and Errea $(2005,2009)$ defined incompatibility as graft union failure because of "cellular physiological intolerance" caused by "metabolic, developmental, and/or anatomical differences between the cultivar and rootstock." Mosse (1962), defined incompatibility as the "failure to form functional vascular connections between the cultivar and rootstock." To understand the mechanism responsible for graft incompatibility, Mosse (1962), attributed graft incompatibility to "translocated" or "located." "Translocated" incompatibility occurs when an occasional factor such as a toxin is translocated from one graft component to the other despite the insertion of a mutual compatibility filter, which does not overcome graft incompatibility. "Located" incompatibility occurs at the graft insertion site and it requires contact between both graft components where insertion of the mutual compatibility filter over comes incompatibility, which can shows the early symptoms in the nursery or over the years. Another symptom that may be related to graft incompatibility is a difference in the diameters of the cultivar and rootstock in the grafting union region (RODRIGUES, 2004; DARIKOVA et al., 2011). Normally, the diameter of the grafted cultivar's trunk is slightly larger than that of the rootstock, which is caused by lignification of the tissue union region. When the cultivar's trunk diameter is much larger than that of the rootstock in the grafting union region, it can be indicative of anatomical grafting incompatibility. This anatomical grafting incompatibility is caused by different rates of rootstock and cultivar cambium cellular division, which lead to discontinuity in the xylem vessels (RODRIGUES, 2004).

According to Pina et al. (2012), the proliferation and adhesion of a tissue callus can occur during the compatible and incompatible grafting of different Prunus combinations up to one week after grafting. However, the formation of new cambium derived from the tissue callus appears to be delayed in heterografts and/or interspecific grafts compared with that in homografts and/or intraspecific grafts. It was found that the plasmodesma coupling inside the graft tissue was highest at the interface in compatible combinations. Thus, it is hypothesized that the callus cells play a central role in the interaction between the cultivar and rootstock, and that the final graft rejection is predetermine during the early stages of graft formation (CIOBOTARI et al., 2010).

The aim of the present study was to evaluate the graft compatibility among combinations of european pear Abbè Fetel, Rocha and Williams cultivars with the East Mailing "C" (EMC) quince rootstock in southern Brazil during the 2011/12, 2012/13 and 2013/14 growing seasons.

\section{MATERIAL AND METHODS}

The experiments were carried out in a commercial european pear orchard located in Urupema municipality, State of Santa Catarina, southern Brazil $\left(28^{\circ} 17^{\prime} 38^{\prime \prime} \mathrm{S}\right.$ and $\left.49^{\circ} 55^{\prime} 54^{\prime \prime} \mathrm{W}\right)$, at an altitude of $1425 \mathrm{~m}$ above sea level, during the 2011/12, 2012/13 and 2013/14 growing seasons. The climate in this region is humid mesothermic (Cf-A) according to the Köppen classification (PEEL et al., 
2007). High precipitation occurs throughout the year and the annual average rainfall and temperature are around $1789 \mathrm{~mm}$ and $14^{\circ} \mathrm{C}$, respectively (EPAGRI, 2013). The soil is a Nitosol with high clay $(60 \%)$ and organic matter $(6 \%)$ content.

The orchard was planted in 2006 with preformed seedlings of european Abbè Fetel, Rocha and Williams pear cultivars, which were grafted using the english grafting method on to EMC quince rootstocks. The orchard trees were trained to slender spindles at a high density with a spacing of $4,0 \mathrm{~m} \square$ $0,5 \mathrm{~m}$, with a plant density of 5.000 plants $\mathrm{ha}^{-1}$. The trees were approximately $3,0 \mathrm{~m}$ in height.

Graft compatibility was evaluated based on plant growth variables and by analyzing the vascular connection at the graft union region at eight years after grafting on to seedlings. The assessed plant variables comprised: a) the trunk section increment $(\mathrm{mm})$ of the cultivar in the graft union region; b) the trunk section increment $(\mathrm{mm})$ of the rootstock in the graft union region; c) the difference in diameter between the grafted cultivar and rootstock; d) "translocated" incompatibility; e) "located" incompatibility; and f) by assessing the vascular connection in the graft union region by immersing the bases of the plants (below the graft union region) in $0.08 \%$ succinic acid solution.

Labeled plants were painted with plastic ink $5 \mathrm{~cm}$ above and below the graft region to guarantee that the exact point was measured for the "a," "b" and "c" plant growth variables during the three years of the evaluation; these variables were used to verify the possible signs of morphological incompatibility. The measurements were made using a digital caliper. The "translocated" incompatibility was evaluated based on the average chlorophyll content (SPAD index) using a portable chlorophyll meter (SPAD-502), with whole and healthy leaves from the plant. The SPAD was assessed for 30 fully developed leaves per parcel (each parcel comprised 10 leaves per plant (one leaf per quadrant) for each treatment at 150 days after full bloom. The leaf tonality varied from green is yellow (chlorotic) to dark green during that period. Therefore, a lower SPAD index indicated greater "translocated" incompatibility (ZARRROUK, 2010).

"Located" incompatibility was analyzed based on the external and internal anatomy of the graft union regionat eight years after grafting on to seedlings, as described by Mosse and Herrero (1951). The "located" incompatibility index ranged among the following classes: A, perfect graft tissue union with no visible lines; B, good graft tissue union, where the union lines were continuous in the wood and bark, although the wood lines were often not visible because ofthe excessive number of stripes; $C$, graft tissue union with bark discontinuity, where the cultivar and rootstock wood tissues were separated by a dark-brown layer with a bark-like appearance; $\mathrm{D}$, graft tissue union with vascular discontinuity, where the cultivar and rootstock wood tissues were separated, while the bark tissue resembled that of class $\mathrm{C}$ in appearance; or $\mathrm{E}$, the graft tissue union was broken in the orchard or greenhouse. Classes A, B, and $\mathrm{C}$ were considered "compatible" unions because there were no effects on the mechanical resistance of the plant. Classes D and E were considered "incompatible" unions because breakage might occur because of mechanical damage or from the wind.

The labeled plant trunk was cut transverselyat $10 \mathrm{~cm}$ above and below the grafting point to observe the vascular connection between the cultivar and rootstock. The sectioned trunks were immediately submitted to an ultrapure water dropping procedure for $1 \mathrm{~h}$ to expel air from inside the xylem and phloem vessels and to prevent the "cavitation" process. The same procedure was then repeated, but the ultrapure water was replaced with succinicacid $(0.08 \%)$ in order to dye the conducting vessels in the grafting union region. The dyed trunk segments were cut longitudinally to view the continuous conducting vessels based on the accumulation of succinic acid stain in the grafting union region. The stained conducting vessels were photographed with a Fuji Film Finepix S3300 camera.

The experiment was arranged in a completely randomized design with three treatments with three replicates, using five plants per experimental plot. The results were compared using analysis of variance (ANOVA) and the means were compared with Duncan's multiple range test with a $5 \%$ probability of error.

\section{RESULTS}

The european Rocha and Abbè Fetel pear cultivars grafted on to the quince EMC rootstock exhibited greater vigor according to the section increment $(\mathrm{mm})$ in the cultivar's trunk at the graft union region and the section increment $(\mathrm{mm})$ in the rootstocks trunk at the graft union region, because partial tissue continuity existed in the graft union region between the cultivars and rootstocks.

The Williams/EMC combination had the greatest difference in diameter between the grafted cultivars and rootstocks compared with the other combinations (Table 1). This high value indicated high tissue incompatibility between the EMC 
rootstock and the Williams cultivar.

The Williams/EMC and Abbè Fetel/EMC combinations showed the lowest and highest SPAD indices, respectively. According to Mosse and Herrero (1951), the SPAD indices indicated that the Williams/EMC combination exhibited "translocated" incompatibility whereas the Abbè Fetel/EMC combination did not (Table 2).

The Williams/EMC combination also exhibited "located" incompatibility according to the macroscopic anatomical evaluation of the graft union region. This "located" incompatibility was demonstrated by the vascular discontinuity in the graft union region that did not allow the passage of the succinic acid stain and subsequent browning of the internal part of the wood near the graft union region (Figures 1 and 2). In this case, the "located" incompatibility index was assigned to class " $D$ " because the graft tissue union exhibited vascular discontinuity, where the cultivar and rootstock wood tissues had separated, while the bark tissue resembled that of class " $\mathrm{C}$ " in appearance (Table 2).

The Rocha/EMC and Abbè Fetel/EMC combinations exhibited partial discontinuity in the bark and xylem vessels tissues between the cultivars and rootstocks based on the accumulation of succinic acid staining in the graft union region (Figure 1). According to the classification proposed by Mosse and Herrero (1951), the combinations of Rocha/EMC and Abbè Fetel/EMC belonged to class " $C$," where the graft tissue union exhibited bark discontinuity and the wood tissues of the rootstock and cultivars were separated by a dark-brown layer, but there were no effects on mechanical resistance.

As described above, in the eight-year-old grafted orchard, the incompatible graft union between the Williams cultivar and EMC rootstock show smooth surface at the point of separation between the cultivar and rootstock, except at the central cylinder point, which was splintered. Apparently, the cultivar and rootstock were compatible in the first few years after grafting; thus, the xylem (wood) bridged the gap during that period. After the delayed incompatibility set in, no further bridging-xylem formed; thus, the smooth cultivar and rootstock surfaces remained in contact but they were not anatomically connected, there by resulting in disruption of the graft union.

\section{DISCUSSION}

In this study, partially compatible and incompatible graft combinations of Rocha/EMC, Abbè Fetel/EMC and Williams/EMC grown for three years in a commercial orchard could be distinguished based on histological data and classification of the structure of the graft interface. Pasa et al. (2012), showed a certain level of incompatibility among european Packham's Triumph and Carrick pear cultivars and quince rootstock, which caused a productivity reduction. According to the authors, these cultivar/rootstock incompatibility occurred because less vigorous rootstocks showed smallest truck diameter at the craft union when compared to normal truck diameter localized below and above the graft union.

The Abbè Fetel and Rocha pear cultivars showed greater vigor than Williams cultivar that showed a total incompatibility in the graft union region between the cultivar and rootstock. The high vigor cultivars were probably attributable to various factors; for instance, the EMC rootstock allowed less succinic acid stain deposit at the graft union region due to high connectivity among xylem conducted vessels (Table 1), because of partial compatibility in the graft union region. The union lines in the bark and wood were partially continuous, allowing the passage of the succinic acid stain through the vascular bundles, whereas this did not occur with the Williams/ EMC combination that showed an incompatible graft union region (Figure 1). The discontinuity of the xylem vessels obstructed the flow of sap into the Williams cultivar and negatively affected vegetative growth (CIOBOTARI et al., 2010).

In the incompatible pear/quince grafts, the interface in the bark had the appearance of a sharp line, which delimited the tissues of each partner, whereas a gradual multilayered transition zone formed in the compatible grafts. In the incompatible grafts, the boundary between the graft and rootstock could be followed from cell to cell because of the difference in the intensity of succinic acid staining between the graft and rootstock. These findings support the view that incompatibility symptoms are initiated in the bark before spreading inward to cause cambium disruption (RODRIGUES et al., 2004; GIACOBBO et al., 2007; PIO et al., 2008; MILOSEVIC et al., 2011).

The main contributor to the strength of any graft union is the formation of a xylem bridge between the cultivar and rootstock, which involves the deposition of lignin in the secondary cell walls of the xylem cells, as Pina and Errea (2009). The theory of graft incompatibility first proposed by Santimore (1988), is that the incompatibility between the cultivar and rootstock combinations prevents normal lignification because of incompatible peroxidases, which are the enzymes that catalyze the process of lignification. Limited and inconclusive evidence supports this explanation. Other mechanisms that 
have been proposed to explain graft incompatibility include abnormal cellular "recognition" between the cultivar and rootstock, and hormonal anomalies, but there is little evidence to support these theories (PINA and ERREA, 2009).

According to Rodrigues et al. (2004), Pio et al. (2008) and Francescatto et al. (2010), the greatest difference in the diameter between the rootstock and cultivar may be an indicator of morphological incompatibility. This morphological incompatibility leads to root system exhaustion because of deficient translocation in the graft union region (ZARROUK et al., 2010; MILOSEVIC et al., 2011). The higher the morphological incompatibility, lower the SPAD index because the leaf chlorophyll concentration is an indication of graft health. Morphological incompatibility is associated with discontinuity in the xylem and phloem vessels, which hinders the flow of sap to the cultivars well as increasing carbohydrate accumulation in the upper parts of the plant (ZARROUK et al., 2010). Pina and Errea (2005, 2009), showed that the vascular discontinuity associated with phloem degeneration in the graft union region had harmful effects on the ascending water flow through the xylem and the descent of photo-assimilates through the phloem.

Elucidating the graft incompatibility mechanisms between the cultivars and rootstocks may help to avoid potential problems before performing grafts (DARIKOVA et al., 2011). Grafting incompatibility can cause major damage to commercial orchards by negatively affecting plant vegetative growth and thus reducing the potential yield.

TABLE 1- Trunk diameter increment $(\mathrm{mm})$ in cultivars at the graft union region (DIC), trunk diameter increment $(\mathrm{mm})$ in the rootstock at the graft union region (DIR), and the difference in the trunk diameters of the cultivar and rootstock at the graft union region (TDD) for different combinations of european pear cultivars and the quince rootstock East Malling " $\mathrm{C}$ " $(\mathrm{EMC})$ during the 2011/2012, 2012/2013 and 2013/2014 growing seasons in southern Brazil.

\begin{tabular}{lccc}
\hline \multicolumn{1}{c}{ Combination } & DIC $(\mathbf{m m})$ & DIR $(\mathbf{m m})$ & TDD $(\mathbf{m m})$ \\
\hline Abbè Fetel/EMC & $11.7 \mathrm{a}^{*}$ & $15.3 \mathrm{a}$ & $3.6 \mathrm{~b}$ \\
Rocha/EMC & $10.0 \mathrm{a}$ & $14.3 \mathrm{a}$ & $4.3 \mathrm{~b}$ \\
Williams/EMC & $10.7 \mathrm{~b}$ & $3.7 \mathrm{~b}$ & $7.0 \mathrm{a}$ \\
\hline Coefficient of variation $(\%)$ & 13.7 & 7.84 & 23.2 \\
\hline
\end{tabular}

*Means followed by the same letter in the same column are not significantly different according to Duncan multiple range test $(P<$ $0.05)$.

TABLE 2-Identification of "translocated" incompatibility based on the SPAD index and "located" incompatibility based on anatomical evaluations of the graft union region according to Mosse and Herrero (1951), for different combinations of european pear cultivars and the quince rootstock East Malling "C" (EMC) during the 2011/2012, 2012/2013 and 2013/2014 growing seasons in Southern Brazil.

\begin{tabular}{lcc}
\hline \multicolumn{1}{c}{ Combination } & "Translocated" incompatibility & "Located" incompatibility \\
\hline Abbè Fetel/EMC & $48.4 \mathrm{a} *$ & $\mathrm{C}$ \\
Rocha/EMC & $44.3 \mathrm{~b}$ & $\mathrm{C}$ \\
Williams/EMC & $39.1 \mathrm{c}$ & $\mathrm{D}$ \\
\hline \multicolumn{1}{c}{ CV (\%) } & 4.8 &
\end{tabular}

\footnotetext{
* Means followed by the same letter in the same column are not significantly different according to Duncan's multiple range test $(P<$ 0.05). "Located" incompatibility was classified as follows. A, Perfect graft tissue union with no visible lines; B, good graft tissue union, where the union lines were continuous in the wood and bark, although the wood lines were often not visible because of the excessive number of stripes; C, graft tissue union with bark discontinuity, where the cultivar and rootstock wood tissues were separated by a dark-brown layer with a bark-like appearance; D, graft tissue union with vascular discontinuity, where the cultivar and rootstock wood tissues were separated, while the bark tissue resembled that of class $\mathrm{C}$ in appearance; or $\mathrm{E}$, the graft tissue union was broken in the orchard or greenhouse.
} 
TABLE 3- Cultivars trunk diameter ( $\mathrm{mm}$ ) at the graft union region (TIC), rootstock trunk diameter (mm) at the graft union region (TIR), and the difference in the cultivar and rootstock trunk diameters at the graft union region (TDD) for different combinations of european pear cultivars and the East Malling "C" (EMC) quince rootstock during the 2011/2012, 2012/2013 and 2013/2014 growing seasons in southern Brazil.

\begin{tabular}{|c|c|c|c|}
\hline Combination & TIC (mm) & TIR (mm) & TDD (mm) \\
\hline & \multicolumn{3}{|c|}{ 2011/2012 } \\
\hline AbbèFetel/EMC & $38.6 \mathrm{a}$ & $42.0 \mathrm{a}$ & $4.3 \mathrm{a}$ \\
\hline Rocha/EMC & $39.3 \mathrm{a}$ & $40.7 \mathrm{a}$ & $3.3 \mathrm{a}$ \\
\hline \multirow[t]{2}{*}{ Williams/EMC } & $28.0 \mathrm{~b}$ & $32.6 \mathrm{~b}$ & $4.7 \mathrm{a}$ \\
\hline & \multicolumn{3}{|c|}{$2012 / 2013$} \\
\hline AbbèFetel/EMC & 41.7 & $48.7 \mathrm{a}$ & $7.0 \mathrm{a}$ \\
\hline Rocha/EMC & 44.0 & $47.7 \mathrm{a}$ & $3.7 \mathrm{ab}$ \\
\hline \multirow[t]{2}{*}{ Williams/EMC } & 31.3 & $34.0 \mathrm{~b}$ & $2.6 \mathrm{~b}$ \\
\hline & \multicolumn{3}{|c|}{ 2013/2014 } \\
\hline AbbèFetel/EMC & 50.3 & $57.3 \mathrm{a}$ & $8.0 \mathrm{a}$ \\
\hline Rocha/EMC & 49.3 & $55.0 \mathrm{a}$ & $7.6 \mathrm{a}$ \\
\hline Williams/EMC & 38.7 & $36.3 \mathrm{~b}$ & $-2.3 b$ \\
\hline
\end{tabular}

*Means followed by the same letter in the same column are not significantly different according to Duncan multiple range test $(P<0.05)$.

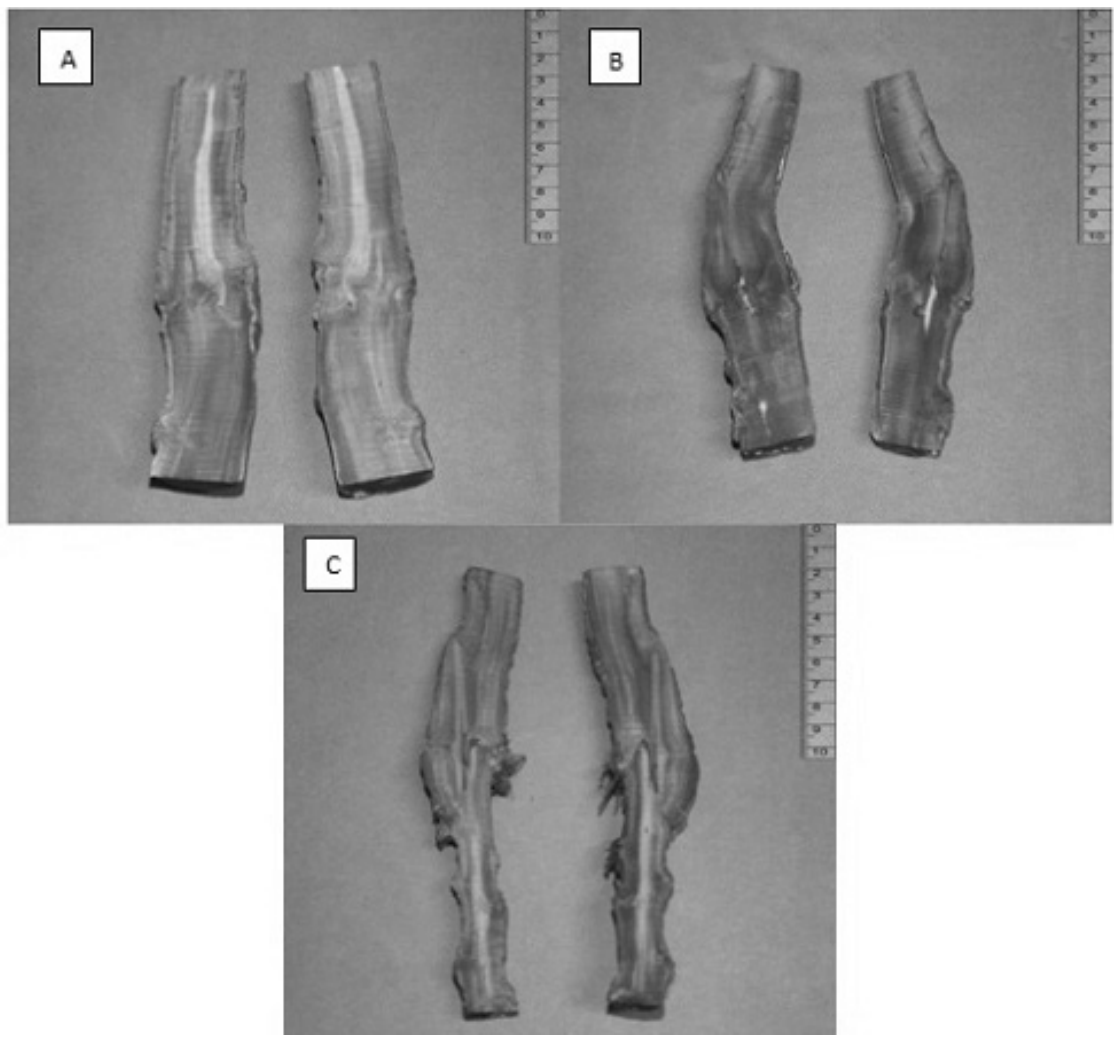

FIGURE 1-Trunk longitudinal internal cross-sections showing the vascular connections in the graft union region eight years after grafting for different combinations of european pear cultivars and the quince rootstock East Malling "C" (EMC): Abbè Fetel/EMC (A); Rocha/EMC (B); and William's/EMC (C) 


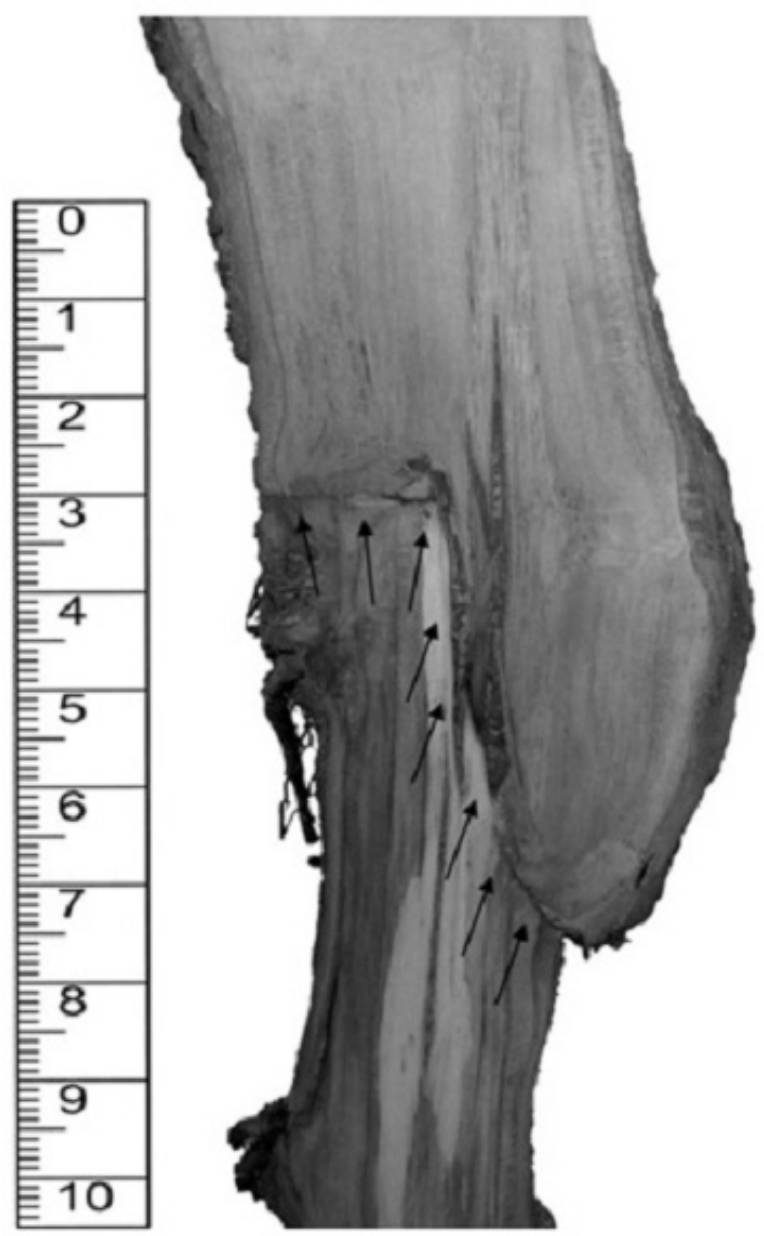

FIGURE 2- Trunk longitudinal internal cross-section of the graft union region in the Williams/EMC combination showing the discontinuous vascular lines, as well as the difference in trunk diameter between the cultivar and rootstock in the graft union region at eight years after grafting.

\section{CONCLUSIONS}

The results of this study showed that the Williams/EMC combination exhibited both "translocated" and "located" incompatibility. Thus, the Williams/EMC combination is considered to be an incompatible combination and it is not recommended for grafting in the field experiment conditions evaluated in this study. The Rocha/ EMC and Abbè Fetel/EMC combinations exhibited tissue discontinuity in the graft union region. The Rocha/EMC and Abbè Fetel/EMC combinations are considered to be partially incompatible.

\section{ACKNOWLEDGMENTS}

This research was financially supported by $\mathrm{CNPq}$ (The National Council for Scientific and Technological Development), FAPESC (Santa Catarina State Foundation for Scientific and Technological Development) and UDESC (Santa Catarina State University). 


\section{REFERENCES}

CIOBOTARI, G.; BRINZA, M.; MORARIU, A.; GRADINARIU, G. Graft incompatibility influence on assimilating pigments and soluble sugars amount of some pear (Pyrus sativa) cultivars. Notulae Botanicae Horti Agrobotanici Cluj-Napoca, ClujNapoca. v.38, p.187-192, 2010.

DARIKOVA, J.A.; SAVVAA, Y.V.; VAGANOVA, E.A.; GRACHEVA, A.M.; KUZNETSOVAB, G.V. Grafts of woody plants and the problem of incompatibility between scion and rootstock (a review). Journal of the Siberian Federal University, Krasnoyarsk v.4, p.54-63, 2011.

EPAGRI - Empresa de Pesquisa Agropecuária e Extensão Rural de Santa Catarina. Dados Meteorológicos de São Joaquim e Videira, SC. Florianópolis: EPAGRI/CIRAM/INMET, 2013.

ERMEL, F.F.; KERVELLA, J.; CATESSON, A.M.; POËSSEL, J.L. Localized graft incompatibility in pear/quince (Pyrus communis/Cydonia oblonga) combinations: multivariate analysis of histological data from 5-month-old grafts. Tree Physiology, Victoria, v.19, p.645-654, 1999.

FACHINELLO, J.C.; PASA, M,S.; SCHMTIZ, J.D.; BETEMPS, D.L. Situação e perspectivas da fruticultura de clima temperado no Brasil. Revista Brasileira de Fruticultura, Jaboticabal, v.33, n.1, p.109-120, 2011. Número especial

FRANCESCATTO, P.; PAZZIN, D.; NETO, A.G.; FACHINELLO, J.C.; GIACOBBO, C.L. Evaluation of graft compatibility between quince rootstocks and pear scions. Acta Horticulturae, The Hague, v.872, p.253-260, 2010

GIACOBBO, C.L.; FACHINELLO, J.C.; PICOLOTTO, L. Compatibilidade entre o marmeleiro portaenxerto cv. EMC e cultivares de pereira. Scientia Agraria, Curitiba, v.8, p.33-37, 2007.

IUCHI, T.; IUCHI, V.L.; HERTER, F.G.; BRIGHENTI, E. Anelamento e paclobutrazol na produção e absorção de nutrientes em pereira (Pyrus communis L.) cultivar Packham's Triumph. Revista Brasileira de Fruticultura, Jaboticabal, v.30, n.4, p.857-861, 2008
JANICK J. Horticultural reviews. New Jersey: John Wiley \& Sons, 2009. v.35, 531 p.

MACHADO, B.M.; RUFATO, L.; BOGO, A.; KRETZSCHMAR, A.A.; MARIO, A.E. Cultivares e portaenxertos sobre o vigor de plantas de pereira europeias. Ciência Rural, Santa Maria, v.43, p.15421545,2013

MILOSEVIC, T.; MILOSEVIC, N. Influence of cultivar and rootstock on early growth and syllepsis in nursery tress of pear (Pyrus communis L., Rosaceae). Brazilian Archives of Biology and Technology, Curitiba, v.54, p.451-456, 2011.

MOSSE, B. Graft incompatibility in fruit trees. Kent: Commonwealth Bureau of Horticulture and Plantation Crops, 1962. 36 p. (Technical Communications, 28)

MOSSE, B.; HERRERO, J. Studies on incompatibility between some pear and quince grafts. The Journal of Horticultural Science, London, v.26, p.238-245, 1951.

PASA, M.S.; FACHINELLO, J.C.; SCHMITZ, J.D.; SOUZA, A.L.K.; FRANCESCHI, E. Desenvolvimento, produtividade e qualidade de peras sobre portaenxertos de marmeleiro e Pyrus calleryana. Revista Brasileira de Fruticultura, Jaboticabal, v.34, n.3, p.873-880, 2012.

PEEL, M.C.; FINLAYSON, B.L.; MCMAHON, T.A. Updated world map of the Köppen-Geiger climate classification. Hydrology and Earth System Sciences, Katlenburg-Lindau, v.11, p.1633-1644, 2007.

PINA, A.; ERREA, P. Morphological and histochemical features of compatible and incompatible stem unions. Acta Horticulturae, The Hague, v.814, p.453-456, 2009.

PINA, A.; ERREA, P.; MARTENS, H.J. Graft union formation and cell-to-cell communication via plasmodesma in compatible and incompatible stem unions of Prunus spp. Science Horticulturae, Amsterdam , v.143, p.144-150, 2012.

PINA, A.; ERREA, P.A review of new advances in mechanism of graft compatibility-incompatibility. Science Horticulturae, Amsterdam, v.106, p.1-11, 2005. 
PIO, R.; CHAGAS, E. A.; BARBOSA, W.; ALVARENGA, A.A.; ABRAHÃO, A.; FELDBERG, N. P.; TOMBOLATO, A. F. C. Graft in quince 'Portugal' on Cydonia and Chaenomeles rootstocks. Revista Brasileira de Fruticultura, Jaboticabal, v.30, n.3, p.850-852, 2008.

RODRIGUES, A.C., FACHINELlO, J.C., SILVA, J.B., FORTES, G.R.L., STRELOW, E., Compatibilidade entre diferentes combinações de cvs. copas e portaenxertos de Prunus $s p$. Revista Brasileira de Agrociência, Pelotas, v.10, p.185189, 2004.
SANTIMORE, J. Graft compatibility in woody plants: an expanded perspective. Journal of Environmental Horticulture, Washington, v.6, p.27-32, 1988.

ZARROUK, O.; TESTILLANO, P.S.; RISUENÕ, M.C.; ANGELES, MORENO, M.; GOGORCENA, $\mathrm{W}$. Changes in cell/tissue organization and peroxidase activity as markers for early detection of graft incompatibility in peach/plum combinations. Journal of the American Society for Horticultural Science, Geneva, v.135, p.9-17, 2010. 